\title{
Preparation and Mechanical Properties of Carbon Nanotubes Reinforced $\mathrm{Al}_{2} \mathrm{O}_{3} / \mathrm{TiC}$ composites
}

\author{
Jing $\mathrm{Li}^{1,}$,, Hui Liu ${ }^{1, b}$ \\ ${ }^{1}$ Shandong Jianzhu University, Jinan, China \\ alijing-ck@163.com, b1083482930@qq.com
}

Keywords: Carbon nanotubes; Hot-pressed sintering; Mechanical properties

\begin{abstract}
Carbon nanotubes reinforced $\mathrm{Al}_{2} \mathrm{O}_{3} / \mathrm{TiC}$ composites were prepared by hot-pressed sintering in vacuum. The preparation technology and mechanical properties of $\mathrm{Al}_{2} \mathrm{O}_{3} / \mathrm{TiC} / \mathrm{CNTs}$ composites were investigated. The results show that the phases of the composites are $\mathrm{Al}_{2} \mathrm{O}_{3}$, TiC and carbon nanotubes. The mechanical properties of $\mathrm{Al}_{2} \mathrm{O}_{3} / \mathrm{TiC} / \mathrm{CNTs}$ composites are significantly improved compared with $\mathrm{Al}_{2} \mathrm{O}_{3} / \mathrm{TiC}$ composites. The bending strength is $556.19 \mathrm{MPa}$ with the increase of $14.40 \%$, the fracture toughness is $4.89 \mathrm{MPa} \cdot \mathrm{m}^{1 / 2}$ with the increase of $10.63 \%$ and the hardness is HRA91.2 at the temperature of $1650^{\circ} \mathrm{C}$ for $30 \mathrm{~min}$ with the pressure of $35 \mathrm{MPa}$. The optimum content of carbon nanotubes is $1.0 \mathrm{wt} . \%$ in this experiment.
\end{abstract}

\section{Introduction}

$\mathrm{Al}_{2} \mathrm{O}_{3}$-TiC composite (denoted by AT) is an important material for structural components due to the high strength, hardness, as well as chemical stability and wear resistance. However, the low fracture toughness still cannot match the command of many practical fields, which greatly limits its applications ${ }^{[1-3]}$. Carbon nanotubes (denoted by CNTs) have attracted great attention as potential strengthening and toughening materials in industrial applications due to their particular structure, low density, high strength and toughness and excellent corrosion resistance ${ }^{[4-7]}$. In this work, carbon nanotubes reinforced $\mathrm{Al}_{2} \mathrm{O}_{3} / \mathrm{TiC}$ composites (denoted by $\mathrm{Al}_{2} \mathrm{O}_{3} / \mathrm{TiC} / \mathrm{CNTs}$ ) were prepared by mechanical milling and hot pressed sintering. The preparation technology and mechanical properties of $\mathrm{Al}_{2} \mathrm{O}_{3} / \mathrm{TiC} / \mathrm{CNTs}$ composites were discussed.

\section{Experimental}

$\mathrm{Al}_{2} \mathrm{O}_{3}$ (average particle size $\sim 30 \mathrm{~nm}$ ) and TiC (average particle size $\sim 80 \mathrm{~nm}$ ) were dispersed into the carbon manotubes suspension with the ethanol as solvent. The mixer with the weight ratio of 70:30 $\left(\mathrm{Al}_{2} \mathrm{O}_{3}\right.$ : TiC) was then homogenized by ball milling for 5 h. The content of carbon nanotubes is $0 w t . \%$ 、 1 wt.\%、1.5wt.\%、2wt.\% respectively. After drying, the $\mathrm{Al}_{2} \mathrm{O}_{3} / \mathrm{TiC} / \mathrm{CNTs}$ powders were hot-pressed and sintered in vacuum. The sintering temperature is $1550-1650{ }^{\circ} \mathrm{C}$, the pressure is $35 \mathrm{Mpa}$ and the holding time is 30min。

Sintered specimens were cut into bars. The final dimensions of these samples were $3 \times 4 \times 36 \mathrm{~mm}$ and $4 \times 2 \times 36 \mathrm{~mm}$ for measuring bending strength and fracture toughness, respectively. The bending strength of samples was measured by a three-point bending test with a support roller span length of $20 \mathrm{~mm}$ and a crosshead speed of $0.5 \mathrm{~mm} / \mathrm{min}$. The fracture toughness $\left(K_{I C}\right)$ was measured by the single-edge notch beam (SENB) method with the span length of $20 \mathrm{~mm}$ and crosshead speed of $0.05 \mathrm{~mm} / \mathrm{min}$. The hardness of the samples was determined using the Rockwell indentation (Model HD-150). The density of specimen was measured by Archimedes' method. The phases of specimen were analyzed by X-Ray diffraction (XRD).

\section{Results and discussion}

Phases of sintered $\mathrm{Al}_{2} \mathrm{O}_{3} / \mathrm{TiC} / \mathrm{CNTs}$ composites

The phases of sintered $\mathrm{Al}_{2} \mathrm{O}_{3} / \mathrm{TiC} / \mathrm{CNTs}$ composites are shown in Fig.1. The result shows that 
the bulk materials are mainly characterized by $\mathrm{Al}_{2} \mathrm{O}_{3}, \mathrm{TiC}$ and carbon nanotubes. There are no new phases appearing.

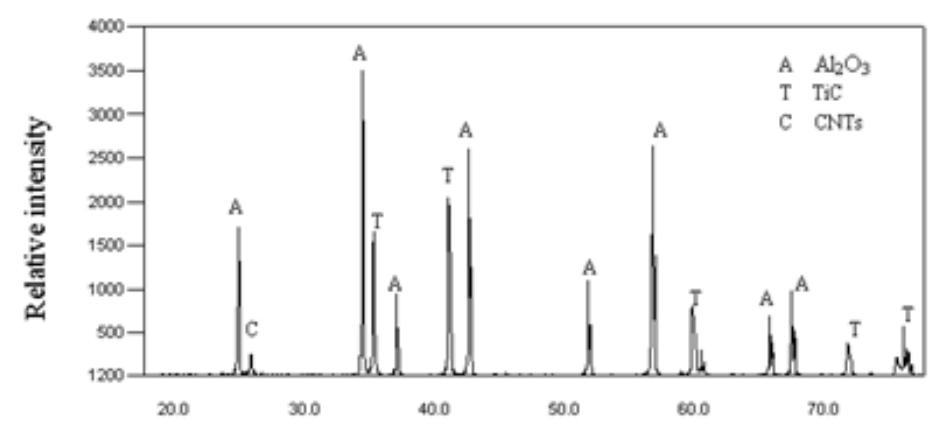

\section{Theta/degree}

Fig.1 XRD pattern of $\mathrm{Al}_{2} \mathrm{O}_{3} / \mathrm{TiC} / \mathrm{CNTs}$ composite

\section{Mechanical properties of sintered $\mathrm{Al}_{2} \mathrm{O}_{3} / \mathrm{TiC} / \mathrm{CNTs}$ composites}

The mechanical properties of $\mathrm{Al}_{2} \mathrm{O}_{3} / \mathrm{TiC} / \mathrm{CNTs}$ ( $\mathrm{ATC}$ ) composites at the temperature of $1650^{\circ} \mathrm{C}$ are listed in table 1 . The results show that the relative density of specimen is more than $98 \%$ at the temperature of $1650^{\circ} \mathrm{C}$.

Table 1 Mechanical properties of $\mathrm{Al}_{2} \mathrm{O}_{3} / \mathrm{TiC} / \mathrm{CNTs}$ composites $\left(1650^{\circ} \mathrm{C}\right)$

\begin{tabular}{cccccc}
\hline material & $\begin{array}{c}\text { Content of carbon } \\
\text { nanotubes(wt.\%) }\end{array}$ & $\begin{array}{c}\text { Hardness } \\
\text { (HRA) }\end{array}$ & $\begin{array}{c}\text { Bending } \\
\text { strength(MPa) }\end{array}$ & $\begin{array}{c}\text { Fracture } \\
\text { toughness(MPa.m }^{1 / 2} \text { ) }\end{array}$ & $\begin{array}{c}\text { Relative } \\
\text { density(\%) }\end{array}$ \\
\hline ATC0 & 0 & 91.0 & 486.19 & 4.42 & 98.1 \\
ATC1 & 1 & 91.2 & 556.19 & 4.89 & 99.3 \\
ATC1.5 & 1.5 & 90.3 & 560.12 & 4.39 & 98.6 \\
ATC2 & 2 & 87.8 & 433.19 & 4.32 & 98.5 \\
\hline
\end{tabular}

Effect of carbon nanotubes content on the relative density.

The relationship of the relative density and carbon nanotubes content of $\mathrm{Al}_{2} \mathrm{O}_{3} / \mathrm{TiC} / \mathrm{CNTs}$ composites is shown in Fig.2. From Fig.2 we can see that with the increase of carbon nanotubes content, the relative density increases at first and decreases later. When the content of carbon nanotubes is less, carbon nanotubes maybe fill into the gap of the substrate and then the density increases. However, with the increase of carbon nanotubes, there are large holes appearing in the substrate because of the aggregation of carbon nanotubes, which leads to the decrease of the density. From Fig. 2 we also can see that the relative density increases with the increase of sintering temperature.

\section{Effect of carbon nanotubes content on the hardness.}

The relationship of the hardness and carbon nanotubes content of $\mathrm{Al}_{2} \mathrm{O}_{3} / \mathrm{TiC} / \mathrm{CNTs}$ composites is shown in Fig.3. From Fig.3 we can see that with the increase of carbon nanotubes content, the hardness increases at first and decreases later. When the content of carbon nanotubes is $1 \mathrm{wt} . \%$, the hardness is up to HRA 91.2 at the temperature of $1650^{\circ} \mathrm{C}$. The hardness is mainly related to the relative density. With the increase of the sintering temperature, the density increases. When the carbon nanotubes content is more than $1 \mathrm{wt} . \%$, the density decreases, which leads to the decrease of the hardness. 


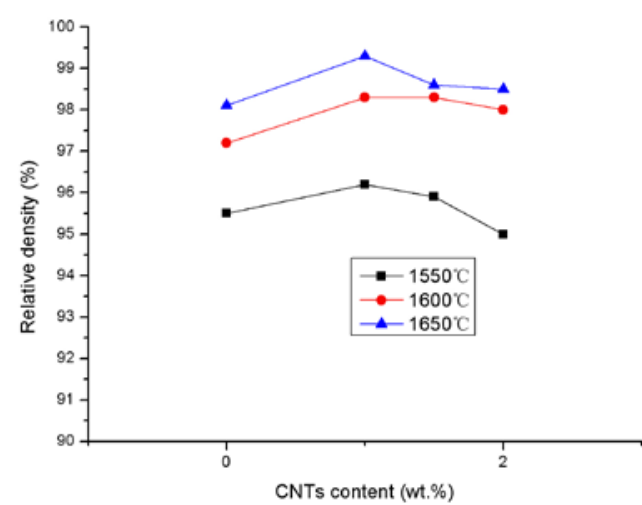

Fig.2 The relative density as a function of carbon nanotubes content
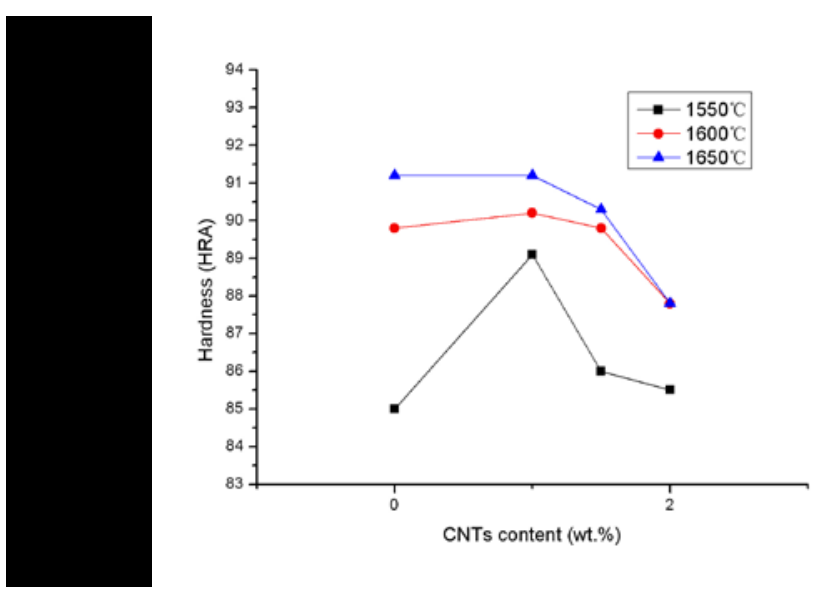

Fig.3 The hardness as a function of carbon nanotubes content

\section{Effect of carbon nanotubes content on the bending strength.}

The relationship of the bending strength and carbon nanotubes content of $\mathrm{Al}_{2} \mathrm{O}_{3} / \mathrm{TiC} / \mathrm{CNTs}$ composites is shown in Fig.4. From Fig.4 we can see that with the increase of carbon nanotubes content, the bending strength increases at first and decreases later. With the increase of the sintering temperature, the density increases and the bending strength is improved. At the temperature of $1650^{\circ} \mathrm{C}$, the bending strength is up to 556.19MPa and 560.12MPa with carbon nanotubes content of $1 \mathrm{wt} . \%$ and 1.5wt.\% respectively. However, the bending strength decreases significantly when the content of carbon nanotubes is $2 \mathrm{wt} . \%$, which may be related to the aggregation of carbon nanotubes.

\section{Effect of carbon nanotubes content on the fracture toughness.}

The relationship of the fracture toughness and carbon nanotubes content of $\mathrm{Al}_{2} \mathrm{O}_{3} / \mathrm{TiC} / \mathrm{CNTs}$ composites is shown in Fig.5. From Fig. 5 we can see that with the increase of carbon nanotubes content, the fracture toughness increases at first and decreases later. The fracture toughness increases because of the fiber toughening effect of a certain amount of carbon nanotubes in the substrate which can prevent crack propagation. But the aggregation of too much carbon nanotubes may destroy the interface between the carbon nanotubes and the substrate, which will weaken the fiber toughening effect. On the other hand, the aggregation of carbon nanotubes leads to the decrease of the density, which may decrease the fracture tougthness. So in this experiment the fracture toughness reaches its maximum with the content of carbon nanotubes $1 \mathrm{wt} \%$ at the temperature of $1650^{\circ} \mathrm{C}$.

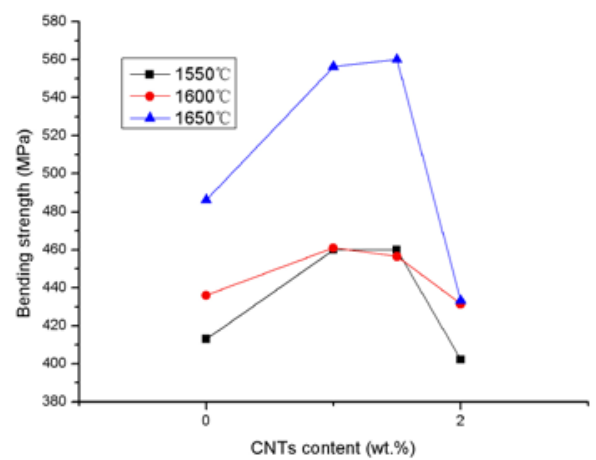

Fig.4 The bending strength as a function of carbon nanotubes content

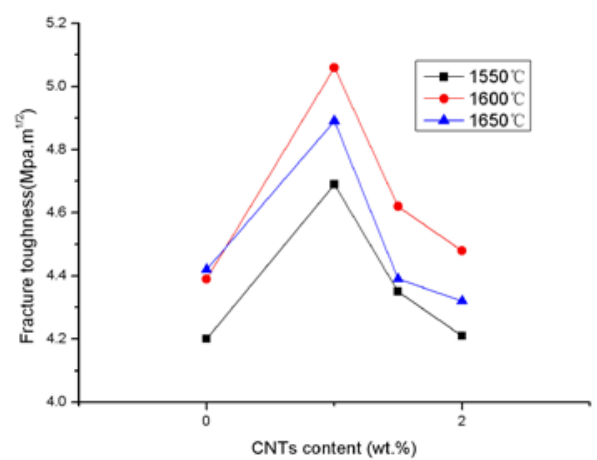

Fig.5 The fracture toughness as a function of carbon nanotubes content 


\section{Conclusions}

1) $\mathrm{Al}_{2} \mathrm{O}_{3}$ powder and $\mathrm{TiC}$ powder are dispersed into the carbon manotubes suspension with the ethanol as solvent and then ball-milled for $5 \mathrm{~h}$. After drying, the $\mathrm{Al}_{2} \mathrm{O}_{3} / \mathrm{TiC} / \mathrm{CNTs}$ powders were hot-pressed and sintered in vacuum. The sintering temperature is $1550-1650{ }^{\circ} \mathrm{C}$, the pressure is $35 \mathrm{MPa}$ and the holding time is $30 \mathrm{~min}$ 。

2) The phases of sintered $\mathrm{Al}_{2} \mathrm{O}_{3} / \mathrm{TiC} / \mathrm{CNTs}$ composites are $\mathrm{Al}_{2} \mathrm{O}_{3}$, TiC and carbon nanotubes. There are no new phases appearing.

3) The mechanical properties of $\mathrm{Al}_{2} \mathrm{O}_{3} / \mathrm{TiC} / \mathrm{CNTs}$ composites are significantly improved compared with $\mathrm{Al}_{2} \mathrm{O}_{3} / \mathrm{TiC}$ composites. The bending strength is $556.19 \mathrm{MPa}$ with the increase of $14.40 \%$, the fracture toughness is $4.89 \mathrm{MPa}^{1 / 2}$ with the increase of $10.63 \%$, and the hardness is HRA 91.2 at the temperature of $1650^{\circ} \mathrm{C}$ with the carbon nanotubes content of $1.0 \mathrm{wt} . \%$.

\section{References}

[1] Lee J H, Ko S K, Won C EW. Sintering behavior of $\mathrm{Al}_{2} \mathrm{O}_{3}-\mathrm{TiC}$ composite powder prepared by SHS process[J]. Materials Research Bulletin, 2001, 36: 989-996.

[2] Yin Y S, Shi R X, Ma L P. Sintering and mechanical properties of $\mathrm{Al}_{2} \mathrm{O}_{3} /$ TiCp composites[J]. Interceram, 2004, 53: 24-27.

[3] Li J, Ma L P. Influence of cobalt phase on mechanical properties and thermal shock performance of $\mathrm{Al}_{2} \mathrm{O}_{3}$-TiC composites[J]. Ceramic International, 2005, 31: 945-951.

[4] Seung I. Cha, kyung T. Kim, Kyong H. Lee, et al. Strengthening and toughening of carbon nanotube reinforced alumina nanocomposite fabricated by molecular level mixing process[J]. Scripta Materialia, 2005, 53:793-797.

[5] Tong Wei , Zhuangjun Fan, Guohua Luo, Fei Wei. A new structure for multi-walled carbon nanotubes reinforced alumina nanocomposite with high strength and toughness[J]. Materials Letters, 2008, 62: 641-644.

[6] Iftikhar Ahmada, Hongzhi Caob, Huahui Chenb, et al. Carbon nanotube toughened aluminium oxide nanocomposite [J]. Journal of the European Ceramic Society, 2010, 30: 865-873.

[7] BALAZSI CS, KONYA Z, WEBER F, et al. Preparation and characterization of carbon nanotube reinforced silicon nitride composites[J]. Materials Science and Engineering, 2003, 23(68):1133-1137. 